\title{
A Review of the Quality Improvement in Discharge Planning through Coaching in Nursing
}

\author{
Candra Dewi Rahayu' ${ }^{1}$, Tri Hartiti², Muhamad Rofi' ${ }^{3}$ \\ ${ }^{1}$ Faculty of Health Sciences University of Science Al Qur'an Wonosobo, Indonesia \\ ${ }^{2}$ Faculty of Health Sciences, Muhammadiyah University of Semarang, Indonesia \\ ${ }^{3}$ Department of Nursing, Faculty of Medicine, Diponegoro University, Indonesia \\ Corresponding author: candra.ners@gmail.com
}

\begin{abstract}
Background: Discharge planning quality will improve the quality of nursing care, patient's self-reliance, quality of life, self-efficacy, and reduce the recurrence rate and LOS (Length of Stay) as well as reduce the cost. Coaching is a method to increase professionalism in the delivery of nursing and caring. Coaching in nursing will improve the nurses' skills, knowledge and motivation in providing nursing discharge planning.

Purpose: The study aimed to review coaching in nursing to improve the quality of discharge planning.

Methods: A literature review was done by collecting the results of scientific publications within 2011-2016 from databases such as EBSCO, ProQuest, PubMed, Google scholar, and the American Journal of Nursing (AJN). Searching was done using the keywords of "coaching", "nurse", "supervision" and "discharge planning".

Results: Six scientific publications were selected in accordance with the criteria of this research. Those publications were of quantitative correlation, experimental and qualitative studies. Results of the review showed that the discharge planning is part of nursing care. Coaching is a competence which must be possessed by nursing managers. Unfortunately, majority of managers were still lacking in their ability to conduct coaching to nurses.

Conclusion: Coaching is important for nurses to improve the quality of discharge planning. However, many nurses still have limitation on their capability to do couching. It is recommended that nurses are given couching trainings to develop their ability in couching.
\end{abstract}

Keywords: discharge planning, nursing, coaching, supervision 


\section{BACKGROUND}

The quality of discharge planning will improve the nursing care quality and patients' life quality. Discharge planning can improve individual coping, patients and family's self-efficacy to improve the patients' quality of life by reducing the recurrence rate to $60 \%$ (Ekim, 2015; Wahyuni et al., 2012). Discharge planning is an integrated and comprehensive act as the efforts to prepare patients' returning or transferring (Jane et al., 2013; Pemila et al., 2010).

A continued and well-structured discharge planning can reduce the number of repeat visits to the hospital with the same complaint which can even decrease the rate of complications (Zekry et al., 2011; Jane et al., 2013). A well-structured discharge planning can reduce LOS (Length of Stay) and treatment costs (Wrobleski et al., 2014; Purnamasari, 2014) which is one indicator of health care quality (Wee et al., 2014).

In America, more than $14 \%$ of hospitalized patients were re-treated with the same problem within 30 days after discharge. Agency for Health Care Research and Quality (ARHQ) stated that the discharge of patients from hospitals can be dangerous and cause complications, which were experienced by $20 \%$ of patients after three weeks of discharge. Three-quarters of the incidents can be prevented during hospitalization with the application of good discharge planning (Agency for Health Care Research and quality, 2015). The effect of discharge planning upon admission and their written goals, brochures or leaflet, and a video planning followed by a telephone follow-up action in 48-72 hours after discharge and 10-14 days after the return has proven to increase readiness, satisfaction and more confidence feeling about the care which must be observed (Hager, 2010).

The implementation of discharge planning has not been done optimally due to the lack of planning, discharge planning policy implementation which is lacking of power, the lack of coordination and communication among health team (Wong et al., 2011). In Sydney, Australia the implementation of discharge planning has not been implemented properly by $23 \%$ due to the lack of nurse's compliance (Jane et al. 2013). Another study describes the officer knowledge about the purpose of discharge planning. Motivation in doing discharge planning as well as their supervision will affect the implementation of the discharge planning process (Hartono et al., 2014; Natasia et al., 2014).

Coaching is one way for the nurse managers to supervise (Brinkert, 2011; Brock, 2008; Nursalam, 2012; Subramaniam et al., 2015). Coaching supports the persons' potential to maximize their performance (Nurhayani, 2011). Coaching does not provide new knowledge or skills, but helps coachee apply the knowledge, skills learned and previous successful experience to yield the best performance (Neale et al., 2009).

Nurse managers should be able to perform the function of actuating and controlling management when supervise. Thus, it motivates nurses carrying out discharge planning according to the standards. A good nursing human resource management is indicated by the nurse managers' ability to conduct supervision, direction and guidance as well as to give full attention to what is assigned and becomes the staff's responsibility. Guidance 
and direction are the function embedded in task of supervision from nurse manager to staff.

Coaching which is conducted by the manager to the nurse practitioners can improve the skills and knowledge so that it will improve the work performance (Cynthia, 2013; Fielden et al., 2009). Coaching is a guidance method that can be developed to improve the quality of nursing resources which will improve the caring quality provided to patients and families. Coaching may improve job satisfaction, intrapersonal ability, interpersonal skills, the system of thinking, ability to leverage the strengths within organizations, self-awareness, working balance and self-caring. In addition, coaching is also able to reduce job stress, burnout and anxiety (Chyntia, 2013), and can be an effort to implement in the workplace (Batson \& Yoder, 2012). Since couching brings a lot of benefits for nurses to improve the quality of discharge planning, and also limited number of reviews on this topic in Indonesia, therefore, it is important for nurses and other health care providers to explore more about couching to improve discharge planning quality.

\section{OBJECTIVE}

The objective of this study is to review coaching in nursing to improve the quality of discharge planning.

\section{METHODS}

Inclusion criteria were articles of qualitative research, correlation and experimental designs published in 2011-2016 written in Indonesian and English. Selected articles were the ones focusing discharge planning which were related to nurse managers and nursing care documentation.

This literature review was carried out by collecting the results of scientific publications in 2011-2016 with from databases such as EBSCO, ProQuest, PubMed, Google scholar, Google search, the American Journal of Nursing (AJN). Searching was done using the keywords of "coaching", "nurse", "supervision" and "discharge planning".

Data from the articles were reviewed using CASP tools and extracted, and then classed as for triangulation to be discussed and summarized in order to know the quality of the articles. Determining the quality of the articles was done by categorizing the percentage of extraction results into good quality, fair quality and poor quality.

Data were collected based on the objectives. All equal samples and result were then analyzed (Table 1). Therefore, it can be seen the heterogeneity of the results found in the study (scientific publications). If the findings did not match the criteria or the results and did not show the established result, then the articles were deleted. This systematic review aimed to reinforce the results of the study / the research. 
Nurse Media Journal of Nursing, 6 (1), 2016, 22
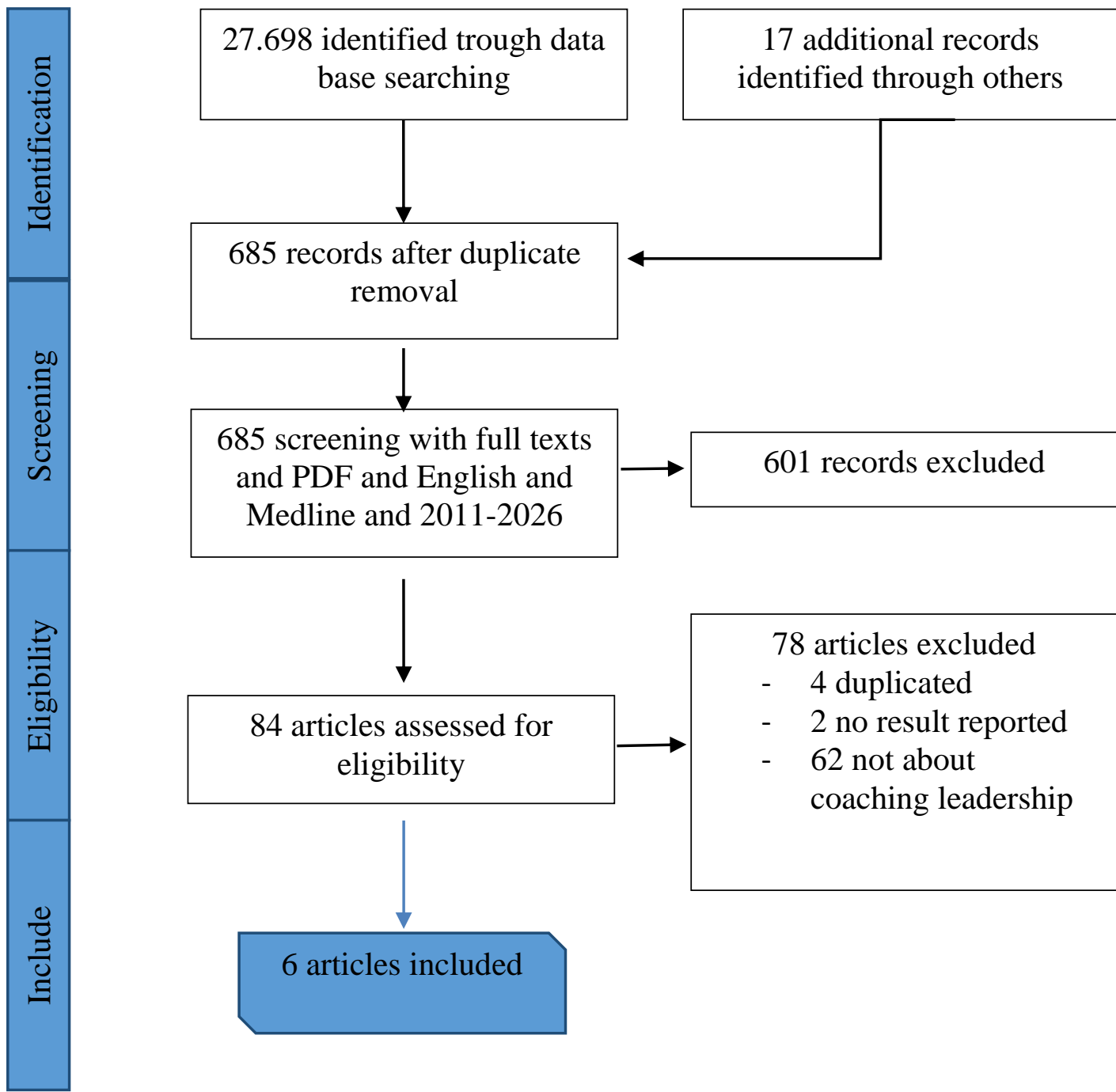

6 articles included

Figure 1. Flow diagram of studies included in this systematic review 
Table 1. The Summary of Articles $(N=6)$

\begin{tabular}{|c|c|c|c|c|c|}
\hline No & $\begin{array}{l}\text { Writer/ } \\
\text { Year }\end{array}$ & Title & $\begin{array}{l}\text { Journal/ } \\
\text { Method }\end{array}$ & Objectives & Results \\
\hline 1 & $\begin{array}{l}\text { Natasia, } \\
\text { Andarini, \& } \\
\text { Koeswo, } \\
2014\end{array}$ & $\begin{array}{l}\text { Hubungan antara Faktor } \\
\text { Motivasi dan Supervisi } \\
\text { dengan Kinerja Perawat } \\
\text { dalam } \\
\text { Pendokumentasian } \\
\text { Discharge Planning di } \\
\text { RSUD Gambiran Kota } \\
\text { Kediri } \\
\text { (Relationship between } \\
\text { Motivation and } \\
\text { Supervision Factors and } \\
\text { the Work Performance of } \\
\text { Nurses in Documenting } \\
\text { Discharge Planning at } \\
\text { Gambiran Hospital } \\
\text { Kediri) }\end{array}$ & $\begin{array}{l}\text { JAM (Jurnal } \\
\text { Aplikasi } \\
\text { Manajemen) } \\
\text { Observational } \\
\text { correlation } \\
\text { with cross } \\
\text { sectional } \\
\text { approach }\end{array}$ & $\begin{array}{l}\text { To find out the } \\
\text { correlation } \\
\text { between } \\
\text { motivation and } \\
\text { supervision by } \\
\text { observing nurses' } \\
\text { working } \\
\text { performance in } \\
\text { discharge } \\
\text { planning } \\
\text { documentation }\end{array}$ & $\begin{array}{l}\text { Correlation between } \\
\text { motivation and } \\
\text { supervision of nurse's } \\
\text { performance in } \\
\text { discharge planning } \\
\text { documentation. } \\
\text { Supervision factors } \\
\text { have more influence on } \\
\text { discharge planning } \\
\text { documentation rather } \\
\text { than motivational } \\
\text { factors }\end{array}$ \\
\hline 2 & $\begin{array}{l}\text { Subramania } \\
\text { m, Silong, } \\
\text { Uli \& Ismail, } \\
2015\end{array}$ & $\begin{array}{l}\text { Effects of coaching } \\
\text { supervision, mentoring } \\
\text { supervision and abusive } \\
\text { supervision on talent } \\
\text { development among } \\
\text { trainee doctors in public } \\
\text { hospitals: moderating } \\
\text { role of clinical learning } \\
\text { environment }\end{array}$ & $\begin{array}{l}\text { BMC Medical } \\
\text { Education/ } \\
\text { A } \\
\text { questionnaire- } \\
\text { based critical } \\
\text { survey }\end{array}$ & $\begin{array}{l}\text { To identify } \\
\text { the extent to } \\
\text { which supervisory } \\
\text { styles (coaching, } \\
\text { mentoring and } \\
\text { abusive } \\
\text { supervision) can } \\
\text { facilitate talent } \\
\text { development } \\
\text { among trainee } \\
\text { doctors in public } \\
\text { hospital }\end{array}$ & $\begin{array}{l}\text { There is a positive } \\
\text { association between } \\
\text { coaching supervision } \\
\text { with } p=.001 \text { and } \\
\text { mentoring supervision } \\
\text { with } p=.019 \text { against the } \\
\text { communication, } \\
\text { personal and } \\
\text { professional clinical } \\
\text { competence } \\
\text { development } \\
\text { There was no } \\
\text { significant abusive } \\
\text { supervision } \\
\text { relationship on } \\
\text { development } \\
\text { competency with } \\
p=.597\end{array}$ \\
\hline 3 & Baxter, 2013 & $\begin{array}{l}\text { The effect of coaching } \\
\text { on nurse manager } \\
\text { leadership of unit base } \\
\text { performance } \\
\text { improvement: } \\
\text { exploratory case study }\end{array}$ & $\begin{array}{l}\text { Unpublished } \\
\text { Thesis. } \\
\text { Unversity of } \\
\text { Kentucky } \\
\text { Intervention } \\
\text { study using } \\
\text { case method }\end{array}$ & $\begin{array}{l}\text { To examine the } \\
\text { effectiveness of a } \\
\text { coaching } \\
\text { intervention on } \\
\text { the performance } \\
\text { improvement of } \\
\text { competence and } \\
\text { skill } \\
\text { acquisition of } \\
\text { nurse managers } \\
\text { leading a unit } \\
\text { based } \\
\text { performance } \\
\text { improvement } \\
\text { team of } \\
\text { the staffs; and to } \\
\text { identify the key } \\
\text { attributes of } \\
\text { coaching in the } \\
\text { setting }\end{array}$ & $\begin{array}{l}\text { Coaching is able to } \\
\text { increase nurse } \\
\text { competence. } \\
\text { Coaching is a } \\
\text { competency that should } \\
\text { be possessed by a } \\
\text { nursing manager. } \\
\text { Improvement of } \\
\text { manager's coaching } \\
\text { ability to boost staff's } \\
\text { performance. }\end{array}$ \\
\hline 4 & $\begin{array}{l}\text { Nurhayani, } \\
2011\end{array}$ & $\begin{array}{l}\text { Hubungan karakteristik } \\
\text { perawat pelaksana } \\
\text { dengan kemampuan } \\
\text { kepala ruang melakukan }\end{array}$ & $\begin{array}{l}\text { Unpublished } \\
\text { Thesis, } \\
\text { Universitas } \\
\text { Indonesia }\end{array}$ & $\begin{array}{l}\text { To describe the } \\
\text { relationship } \\
\text { between nurse } \\
\text { practitioners and }\end{array}$ & $\begin{array}{l}\text { The ability of nurse } \\
\text { manager to conduct } \\
\text { counseling (coaching) is } \\
\text { still largely below }\end{array}$ \\
\hline
\end{tabular}




\begin{tabular}{|c|c|c|c|c|c|}
\hline & & $\begin{array}{l}\text { bimbingan (coaching) } \\
\text { menurut persepsi } \\
\text { perawat pelaksana di } \\
\text { ruang rawat inap RS } \\
\text { Haji Jakarta } \\
\text { (Relationship between } \\
\text { the Characteristics of } \\
\text { Nurses and the } \\
\text { Capability of Head } \\
\text { Nurses in Couching } \\
\text { Based on the Perception } \\
\text { of Inpatient Ward Nurses } \\
\text { at Haji Hospital Jakarta) }\end{array}$ & $\begin{array}{l}\text { Correlative } \\
\text { descriptive } \\
\text { cross sectional } \\
\text { approach. }\end{array}$ & $\begin{array}{l}\text { nurse manager's } \\
\text { ability to conduct } \\
\text { counseling }\end{array}$ & $\begin{array}{l}\text { standard which is } 60 \\
(60 \%) \text { The lowest score } \\
\text { is } 60 \text { and a highest score } \\
\text { is } 120 .\end{array}$ \\
\hline 5 & $\begin{array}{l}\text { McNamara et } \\
\text { al., } 2014\end{array}$ & $\begin{array}{l}\text { Mentoring, coaching and } \\
\text { action learning: } \\
\text { interventions in a } \\
\text { national } \\
\text { clinical leadership } \\
\text { development program }\end{array}$ & $\begin{array}{l}\text { (JCN) Journal } \\
\text { of clinical } \\
\text { nursing } \\
\text { A qualitative } \\
\text { design, using } \\
\text { multiple data } \\
\text { sources and } \\
\text { multiple data } \\
\text { collection } \\
\text { methods }\end{array}$ & $\begin{array}{l}\text { To evaluate } \\
\text { mentoring, } \\
\text { coaching and } \\
\text { action learning } \\
\text { interventions } \\
\text { used to develop } \\
\text { nurses' and } \\
\text { midwives' clinical } \\
\text { leadership } \\
\text { competencies; } \\
\text { To describe the } \\
\text { program of the } \\
\text { participants' } \\
\text { experiences of the } \\
\text { interventions }\end{array}$ & $\begin{array}{l}\text { Mentoring, coaching } \\
\text { and action learning } \\
\text { were positively } \\
\text { experienced by the } \\
\text { participants and } \\
\text { contributed to the } \\
\text { development of clinical } \\
\text { leadership } \\
\text { competencies, as stated } \\
\text { by the program } \\
\text { participants and } \\
\text { intervention facilitators. }\end{array}$ \\
\hline 6 & $\begin{array}{l}\text { Brinker, } \\
2011\end{array}$ & $\begin{array}{l}\text { Conflict coaching } \\
\text { training for nurse } \\
\text { managers: a case study } \\
\text { of a two-hospital health } \\
\text { system }\end{array}$ & $\begin{array}{l}\text { Journal of } \\
\text { Nursing } \\
\text { Management } \\
\text { A quantitative } \\
\text { design }\end{array}$ & $\begin{array}{l}\text { To evaluate the } \\
\text { application of the } \\
\text { comprehensive } \\
\text { conflict coaching } \\
\text { model in a } \\
\text { hospital } \\
\text { environment }\end{array}$ & $\begin{array}{l}\text { Benefits included } \\
\text { supervisor conflict } \\
\text { coaching competency } \\
\text { and enhanced conflict } \\
\text { communication } \\
\text { competency for nurse } \\
\text { managers and } \\
\text { supervisees facing } \\
\text { specific conflict } \\
\text { situations. Challenges } \\
\text { included the } \\
\text { management of } \\
\text { program tensions. } \\
\text { Additional benefits and } \\
\text { challenges are } \\
\text { discussed, along with } \\
\text { study limitations. }\end{array}$ \\
\hline
\end{tabular}

\section{RESULTS}

\section{Coaching In Nursing}

Coaching is advocated as a way of developing clinical leadership skills in context, by placing individuals into real situations in which they experience at first hand the unique problems that occur in particular clinical settings (McNamara et al., 2014). Coaching is able to increase nurse competence, coaching is a competency that should be possessed by a nursing manager, Improvement of a manager coaching ability of to boost staff's performance (Chyntia., 2013).

WHO states in the urge to improve the nurse professionalism through effective coaching methods (Nurhayani., 2011). Coaching guidance method is a way to achieve the best 
work performance for individuals and organizations. Coaching supports one's potential to maximize performance (Nurhayani., 2011). Coaching conducted by the manager to the nurses is able to improve the skills and knowledge so that will enhance the work performance (Cynthia., 2013; Fielden et al., 2009). However, the results of research conducted by Nurhayati (2011) showed that $60 \%$ of the nurse managers were still lacking to do counseling.

\section{Coaching Supervision}

Conflict coaching involves a coach working with a client to improve the client's conflict understanding, interaction strategies and/or interaction skills. The training of nurse managers as the conflict coaches is an innovative continuing education program that partially addresses conflict-related concerns in nursing. Benefits include improving supervisor's conflict coaching competency and enhancing conflict communication competency for nurse managers and supervisees facing specific conflict situations.

Challenges include the management of program tensions (Brinkert, 2011).

Coaching and mentoring supervision are positively associated with talent development, and but there is no significant relationship between abusive supervision and talent development. The findings also support the moderating role of clinical learning environment on the relationships between coaching supervision-talent development, mentoring supervision-talent development and abusive supervision-talent development among public hospital trainee doctors. The results showed relationship between coaching supervision and talent development $(\beta=.200, p=.001)$, as well as mentoring supervision and talent development $(\beta=.121, p=.019)$. These values are statistically significant, where the path between abusive supervision and talent development is not statistically significant $(\beta=-.027, p=.597)$ (Subramaniam et al., 2015).

\section{Coaching in Maintaining the Quality of Discharge Planning}

Discharge planning process requires competency of health practitioners in several ways, including the ability to listen to the needs and expectations of clients, the opinion of other health team members and do not just think that they by themselves are able to solve all problems. The understanding of discharge planning process is very important to be owned, since this process is routinely be done in the health service. The confidence of health workers in front of the client also determines the success of discharge planning process. Research on the relationship between the factors of motivation and supervision of nurse's performance in the discharge planning documentation is an observational correlation with cross sectional study. The research instruments used were questionnaires with Likert scale and observational forms of checklist. The data were analyzed using univariate, bivariate, and multivariate analyses. The result of the analysis showed no correlation between motivation and supervision of nurse's performance in the discharge planning documentation. The factor of supervision gave more influence on the discharge planning documentation compared to the motivation one (Natasia et al., 2014).

The results of the analysis of the relationship between supervision and nurse's performance in the discharge planning documentation obtained $p<.05$, which means there is a significant correlation between the factors supervising nurse with discharge 
planning documentation. The results of logistic regression test on motivation variable values obtained $\mathrm{OR}=15.448$ which means that nurses who have high motivation will conduct discharge planning with complete documentation by 15 times compared with nurses who have low motivation. On supervision variable values obtained $\mathrm{OR}=46.667$ which means nurses are supervised well will conduct discharge planning with complete documentation by 46 times compared with nurses who have less supervision (Natasia et al., 2014).

\section{DISCUSSION}

The complexity of disease and chronic illness will affect repeated visits of the same case and lengthen the period of LOS so the nurse should be able to increase the client knowledge, the client's independence, and the client personal status. Discharge planning is programmed and planned to be able to overcome such effects (Pemila et al., 2010; Natasia et al. 2014). It is explained that in order to obtain a high quality discharge planning, a nursing manager must notice the nurse perception in discharge planning, nurse motivation, policy towards the implementation of discharge planning, compliance of implementation of discharge planning, discharge planner team communications, the plan of discharge planning, clients and family agreement and consensus and participation (Jane et al., 2013; Wrobleski et al., 2014; Purnamari 2014; Rahayu, 2014; Rofii et al. 2012).

Discharge planning process demands the nurse manager to be able to carry out good management functions that encourage caregivers to take action in accordance with the standards. Implementation of the action in accordance with the standards (nurse compliances) influenced by motivation, managers monitoring, self-concept, education, knowledge, supervision, punishment and training (Widyaningtyas, 2010; Kamaluddin \& Rahayu 2009). Banner theory states that a manager must have competence in providing guidance, situations management, maintaining the quality of care and as a role model (Numminen et al., 2014) because it will affect nurses in providing care including the implementation of discharge planning. Discharge planning should be programmed and planned to improve the quality of nursing care (Rahayu, 2014). Optimum development of work performance resource to get a high quality discharge planning is carried out with training, coaching, mentoring, and preceptorship (Kok, 2015; Neale et al., 2009).

Coaching is the best assistance method from managers directly and focused discussions and activities guidance to learn to solve problems or perform a better job and build a culture of nursing leadership in clinical care (Serio, 2014). Coaching is a guidance method that can be developed to improve the quality of nursing resources which will improve the quality of care provided to patients and families.

Coaching is a method of continual assistance creating an opportunity for those who receive coaching (coachee) to explore his/her own potential and maximize stage by stage. Coaching is a tool in nursing management function includes a process of Organizing Actuating Planning Controlling (POAC). Coaching is defined as an interactive process between manager and staff to collaborate on accomplishing the problem of performance (Kok, 2015; Verwey et al., 2012). 
Coaching is an indirect empowerment effort, assistance (non-directive) to the coachee, and leads from behind (Pramudianto, 2015). Ministry of Health The Republic of Indonesia in Nurhayani (2011) points out that coaching is an intensive guidance through individuals and practices followed by providing feedback. Coaching is a process which is used as a means of communication between staff and managers where POAC management functions is to achieve alternative solutions to problems, other than that coaching is also used as a tool to assess the staff potential and to improve the performance.

\section{CONCLUSION}

The literature study shows that coaching has a correlation with discharge planning. Discharge planning is very vital for patients and families; nursing management; and hospital management. Coaching is an assistance method which is one of the direct supervision techniques from the managers to the staffs. Well conducted couching is able to improve the nurse's competency and motivation in nursing care and nursing documentation. A manager capability, in this case is the room manager, is still lacking to coach so it is necessary to improve it. Therefore, it will have a positive impact on the quality of discharge planning.

\section{REFERENCES}

Agency for Health Care Research and Qualily (AHQR). (2015). IDEAL Discharge Planning Overview, Process, and Checklist, US. Available at: http://www.ahrq.gov/patients-consumers/index.html.

Batson, V.D. \& Yoder, L.H. (2012). Managerial coaching: a concept analysis. Journal of Advanced Nursing, 68(7).

Brinkert, R. (2011). Conflict coaching training for nurse managers: a case study of a two-hospital health system. Journal of Nursing Management, 19, 80-91.

Brock, V.G. (2008). Grounded teori of the roots and emergence of coaching., International University of Professional Studies.

Chyntia, B. (2013). The effect of coaching on nursing manager leadership of unit base performance improvement: Exkploratory Case Study. Unversity of Kentucky UK. Available at: Uknowladge@1sv.uky.edu.

Discharge Planning Ascocition. (2008). Discharge Planning. Available at: http://www.dischargeplanning.org.au/.

Ekim, A. (2015). Efficacy of a transition teory-base discharge planning program for children ashtma management. International Journal of Nursing Knowladge.

Fielden, S.L., Davidson, M.J. \& Sutherland, V.J. (2009). Innovations in coaching and mentoring: implications for nurse leadership development. Health Services Management Research, 22: 92-99.

Goaldsmit \& Laurence. (2006). Coaching for leadership 2nd ed., San Francesco: Capfiffer.

Hager J.S. ( 2010). Effect of discharge planning intervention on perceived readines for discahrge, doctor of nursing practice system change projec. St. Chaterine University.

Hartono, I., Haryanto, S. \& Subandono, J. (2014). Pelaksanaan discharge planning pada pasien post sectio caesaria [The implementation of discharge planning in post sectio caesaria]. Jurnal Kebidanan dan Keperawatan, Vol. 10. 
Jane, G., Galakher, R. \& Bothe, J. (2013). Nurse Discharge Planning and Risk assessment: Behaviour, understanding and barrier. Journal of Clinical Nursing, ed: 22 . B1.

Kamaluddin, R. \& Rahayu, E. (2009). Analisis Faktor-Faktor yang Mempengaruhi Kepatuhan Asupan Cairan pada Pasien Gagal Ginjal Kronik dengan Hemodialisis di RSUD Prof. Dr. Margono Soekarjo Purwokerto [An Analysis of Factors Influencing Adherence of Water Intake in Patients with Chronic Renal Failure Undergoing Hemodialysis in Prof. Dr. Margono Hospital Purwokerto\}. Jurnal Keperawatan Sudirman, 4. Available at: http://jos.unsoed.ac.id/index.php/keperawatan/article/view/175.

Kok, E.J. (2015). Coaching Genius pertama., Jakarta: PT Gramedia Pustaka Utama.

Natasia, N., Andriani, megah \& Koeswo, M. (2014). Hubungan antara Faktor Motivasi dan Supervisi dengan Kinerja Perawat dalam Pendokumentasian Discharge Planning di RSUD Gambiran Kota Kediri [Relationship between Motivation and Supervision Factors and the Work Performance of Nurses in Documenting Discharge Planning at Gambiran Hospital Kediri]. Jurnal Aplikasi Manajemen (JAM), Vol 12.

Neale, S., Spencer-Arnell, L. \& Wilson, L. (2009). Emotional Intelegent Coaching Improving Performance for Leaders, Coaches and the individual, London and Philadelphia: Kogan Page.

Numminen, O., Laine, T. \& Isoaho, H. (2014). Do educational outcomes correspond with the requirements of nursing practice: educators' and managers' assessments of novice nurses' professional competence. Journal of Caring Sciences, 28; $812-82$.

Nurhayani, S. (2011). Hubungan karakteristik perawat pelaksana dengan kemampuan kepala ruang melakukan bimbingan (coaching) menurut persepsi perawat pelaksana diruang rawat inap rumah sakit haji Jakarta [Relationship between the Characteristics of Nurses and the Capability of Head Nurses in Couching Based on the Perception of Inpatient Ward Nurses at Haji Hospital Jakarta]. Universitas Indonesia.

Nursalam. (2012). Manajemen keperawatan aplikasi dalam praktik keperawatan profesional edisi 3 [Application of nursing management in professional nursing practice., Jakarta: Salemba Medika.

Patricia, P. (2005). Fundamental of Nursing: Concepts, Process and Practice 1st Edition., Jakarta: EGC.

Pemila, U., Sitorus, R. \& Hastono, S.P. (2010). Penurunan risiko kambuh dan lama rawat pada klien stroke iskemic melalui perencanaan pemulangan terstruktur [Decreasing the Risks for Rellapse and Length of Stay in Ischemic Stroke Patients through a Structured Discharge Planning]. Jural Keperawatan Indonesia, , Vol 3 No 3.

Pramudianto. (2015). I'm a Coach Strategi mengembangkan potensi diri dengan coaching ['I am a Coach' Strategy to Develop Self-Potentials through Coaching], Yogyakarta: CV ANDI OFFSET.

Purnamari, I. (2014). Rancangan model perencanaan pulang anak diare studi kasus di RSUD KRT Setjonegoro Wonosobo [Designing a Discharge Planning Model for Patients with Diarrhoea: a Case Study in Setjonegoro Hospital Wonosobo]. Universitas Gajah Mada. Tesis: Tidak dipublikasikan [unpublished]. 
Rahayu, C.D. (2014). Analisis Faktor-Faktor Yang Mempengeruhi Kualitas Discharge Planning Terhadap Tingkat Kemandirian Pasien Dengan Gangguan Cardiovarcular Pasca Hositalisasi [Analysis of Factors Influencing Discharge Planning Quality., p.64. Available at: www.unsiq.ac.id.

Rofii, M., Haryati, R.T. \& Pujasari, S.H. (2012). Perjanjian dan konsensus dalam pelaksanaan perencanaan pulang pada perawat rumah sakit [Agreement and Consesus on the Implementation of Discharge Planning in Hospital Nurses]. Jural Keperawatan Indonesia, Vol. 15.

Salter, M. (2016). Discharge planning Patient and carer satisfaction., 12(8), pp.43-46.

Serio IJ. (2014). Using coaching to create empowered nursing leadership to change lives. Continuing Education in Nursing.

Stephen Neale, L.S.-A. and L.W. (2009). Emotional Intelegent Coaching Improving performance for leaders, coaches and the individual, London and Philadelphia: Kogan Page.

Subramaniam, A. et al. (2015). Effects of coaching supervision, mentoring supervision and abusive supervision on talent development among trainee doctors in public hospitals: moderating role of clinical learning environment. BMC Medical Education, 15:129.

Verwey, R. et al. (2012). A case study of the user-centred design process and testing of a web-based coaching system to stimulate the physical activity of chronically ill patients in primary care. Informatics in Primary Care, 20, pp.289-98.

Wahyuni, A., Nurrocman, E. \& Gayatri, D. (2012). Kesiapan pulang pasien penyakit jantung koroner melalui penerapan discharge planning [Readiness for Hospital Discharge of Coronary Patients by the Implementation of Disharge Planning]. Jurnal Keperawatan Indonesia, 15 N0 3.

Wee, S.-L., Loke, C.-K. \& Liang, C. (2014). Effectiveness of a National Transitional Care Program in Reducing Acute Care Use. The American Geriatrics Society, 62:747-753.

Widyaningtyas, K.S. (2010). Analisis Faktor-Faktor yang Mempengaruhi Kepatuhan Perawat dalam Pendokumentasian Asuhan Keperawatan [Analysis of Factors Influencing Adherence in Nursing Care Documentation]. Institutional Repository (UNDIP-IR). Available at: http://eprints.undip.ac.id/.

Wong, E.L., HK Yam, C. \& WL, A. (2011). Barrier to efective discharege planning: aqualitatif study investigating the perspective of frontline healt care profesional. BMC Healt Cervice, 11:242.

Wrobleski, D.M.S. et al. (2014). Discharge Planning Rounds to the Bedside : A Patientand Family- Centered Approach. , 23(2).

Zekry, D. et al. (2011). High Levels of Comorbidity and Disability Cancel Out the Dementia Effect in Predictions of Long-Term Mortality after Discharge in the Very Old. Dementia And Geriatric Cognitive Disorders, 32, p.103. 